\title{
DOI 10.26886/2414-634X.8(17)2017.4
}

UDC: 372.851

\section{USING PROFESSIONAL CONTENT PROBLEMS IN THE MATHEMATICAL TRAINING PROCESS OF SPECIALISTS IN ECONOMIC SPECIALTIES}

\section{O. M. Tokarchuk}

Mohyliv-Podilskyi assembly-economic colledge, Ukraine, Mohyliv-Podilskyi

The article deals with the problem of improving the quality of mathematical training of future specialists in economic specialties through the use of problems with professional content. The categorical apparatus of the research has been revealed. The issues of classification of problems with professional content on the basis of different characteristics have been considered: according to educational purpose, teaching methods, time, etc. The characteristics of the problems with professional content have been specified. The functions that are fulfilled by such problems have been singled out: educational, developmental, up-bringing, control. The advantages of using problems with professional content in the process of mathematical training of economic specialties students of colleges have been revealed. Requirements for the selection, development and compilation of problems with professional content have been defined. The subject field of interdisciplinary problem book, developed for mathematical training of specialists in colleges of economic profile, has been presented.

Key words: mathematical training, specialists in economic specialties, colleges, problems with professional content, interdisciplinary problems.

Introduction. After fininshing school, some students decide to take up a profession in vocational educational establishments or in technical schools, colleges, etc. Often, students emphasize the study of special 
subjects, at the same time general education and fundamental subjects, which are also obligatory for study, are perceived by students as minor, and possibly unnecessary.

Interest in the study of such an abstract discipline as mathematics leaves much to be desired. Lack of motivation adversely affects the level of students' achievement. Although, mathematical knowledge to a greater or lesser extent (depending on the specialty) is required to perform production functions. In addition, at the mathematics classes, the following qualities are develop, the ones which will be necessary both for professional activity and in everyday life (e.g., logical thinking, imagination, memory, spatial thinking, ability to analyze and generalize, etc.). In addition, after graduating colleges, some students want to continue their studies in higher education institutions, where they will need basic knowledge of mathematics [1, p. 201].

The main part of the mathematical training of specialists in the field of economics and finance is solving problems, because without this type of educational activity it is impossible to master mathematical knowledge and develop practical skills. The results of numerous and different in nature researches confirm the idea that a problem is the major and the most effective development tool of not only mathematical thinking, but also of the creative activity of students. The logical, algorithmic and heuristic components of thinking, as well as moral qualities of personality are formed in the process of solving problems [2].

The question of using interdisciplinary problems in the study process is quite relevant. The works of many scientists, both mathematicians and pedagogues are dedicated to its solving. In particular, solving mathematical problems with practical content was considered by S. Bedenko, A. Korotchenkova, M. Mirzoahmedov, I. Shapiro, L. Shapovalova and others. Particular attention is paid to the works where was considered the 
problem of using the problems of economic and financial content during the study of mathematical disciplines in educational institutions of different levels. In particular, these issues are researched in the works of S. Garaiiev (in a junior secondary school), L. Mezheinikova (in a school), H. Dutka (in economic colleges), T.Krylova (in Technical Higher Educational Establishments), V. Monakhov (in vocational schools) and others.

As many researchers point out, such problems serve as the main means of developing spatial imagination, algorithmic thinking style, creative principle, and contribute to the formation of an active life position of future economists, preparing them for a high quality and efficient functional duties performing in the framework of future professional activity [3]. However, a number of issues relating to differences in definitions, classification of problems, coverage of benefits, and the stages of solving problems haven't been revealed sufficiently enough.

The purpose of the article. Therefore, the purpose of the article is to identify ways to improve the quality of mathematical training of future specialists in the economic sphere through the use of professional content problems, formulation of requirements for such problems and demonstration of the possibilities for their use.

Presenting main material. Let's find out how the term a "problem" is interpreted in pedagogy. There are many approaches to defining the notion of a "problem" that are conditioned by the specifics of a particular science. In the Ukrainian pedagogical dictionary, the problem is defined as the purpose of activity that must be achieved through a specified procedure. The problem in this case contains a requirement (purpose), condition (known), sought-for (unknown). The unknown is formulated in the form of a question [4]. V. Bespalko interprets the problem as a known purpose, achievement of which is possible through certain actions (activities) in a particular situation $[5$, p. 55]. In the methodology of mathematics, the 
interest is not the result of the solution of the problem, but the process itself, since it is precisely in the process of solving that a way of action is formed.

Realization of professional orientation of mathematical disciplines is carried out mainly through a system of special problems with professional content. One of the most effective ways of mastering by the graduates of higher educational institutions the mathematical activity is their solving the problems with a professional and economic component, which has a comprehensive impact on the personality of students: educational, practical, and educational [3].

As the analysis of scientific and pedagogical literature shows, various researchers use various terms "problems with professional content», «professionally directed problems», «problems with interdisciplinary content», "problems with practical content», etc. Let's find out what is meant by these terms.

The researcher M. Mirzoahmedov defines interdisciplinary applied problems as problems of non-mathematical content, for solving of which it is necessary to use all methods of mathematics [6].

L.Shapovalova interprets interdisciplinary problems as problems, the condition, content and process of solving of which integrates the structural elements of knowledge about phenomena of nature and society, which are studied in various disciplines [7, p. 18].

V. Bakhmet believes that professionally directed problems can be interpreted as «a system of interdisciplinary problems of the educational process, which is the unity of the law appropriate and creative and inmprovising activity aimed at developing the professional competence of students and involves achievement of planned results» [8, p. 11]. The researcher $\mathrm{H}$. Kashkanova, understands the educational problems with professional content, as the applied problems that reflect the specifics of future professional activity of students [9, p. 17]. 
L. Shoferovskaya under the mathematical problem with financial content understands the problem, the plot of which reveals the use of mathematics in financial disciplines, acquaints oneself with application of mathematical concepts, operations and laws in the financial sphere of life [10, p. 414].

Having analyzed the above definitions, we conclude that, in general, among all problems we can allocate the problems with applied content, among which, in the context of our study, particular attention is paid to the problems with professional content, namely, financial and economic.

Let's consider the question of classification of problems with professional content. Nowadays there are numerous classifications of such problems according to various characteristics, for example, by educational purposes, teaching method used to implement communication, the number of displayed links, time characteristics, etc. [2].

L. lliashenko proposed the classification of professionally oriented mathematical problems according to the development of certain types of skills:

- ability to build mathematical models (incomplete problems with insufficient data, problems with dynamic forecasting, problems that involve obtaining data using a simple experiment);

- communicative (problems on reading information from the mathematical language);

- algorithmic (problems with predicted result, problems with analysis of the received answer);

- functional (problems on constructing and reading graphs of functions, problems of transition to the analytic form of the function setting, the problem on functional dependence);

- geometric (problems on construction of figures on a plane and in space, problems on finding numerical characteristics of geometric figures); 
- stochastic (problems on the situation analysis, problems on the received answer analysis, problems on assessing the reliability of the result, problems related to the general theory of the experiment) [11].

For example, in order to develop functional skills while studying the topic «Function» of the higher mathematics course, we propose the problem in which students have to compile an analytical expression for a given dependence and, given the properties of the function received, give an economic interpretation of the calculated results.

Example. Make the function of production costs on the output unit $y$ from the production volume $\mathrm{x}$. Analyze what will happen in case of increasing and decreasing of production volume.

Solution. It is known that the production costs have a constant component - we will denote it as $a_{0}$, and the variable component $\frac{a_{1}}{x}$ (students have to substantiate that with increasing of production the costs will decrease, that is, the dependence will be inversely proportional). Consequently, the total costs will be determined by the formula $y=a_{0}+\frac{a_{1}}{x}$. Students should conclude that production costs are described by inverse proportionality, construct a graph of this function (Fig. 1) and provide economic interpretation, that is, to find out that with increasing of production $x$ the costs $y$ will decrease. For a large volume of production $(x \rightarrow \infty)$, the costs per unit of output will be very little different from the constant costs $a_{0}$ $\left(y \rightarrow a_{0}\right)$.

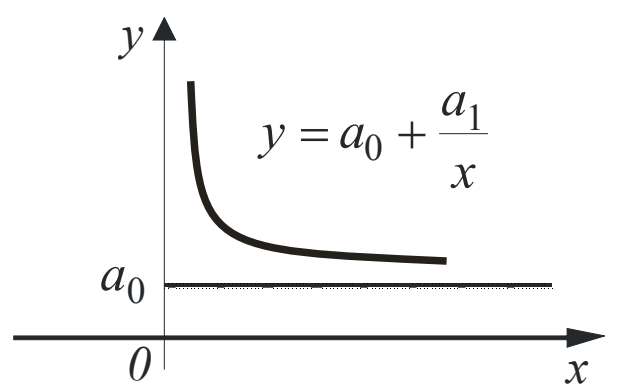




\section{Fig. 1. Function graph $y=a_{0}+\frac{a_{1}}{x}$.}

When conducting classification of interdisciplinary problems in accordance with the educational purpose, they are divided into the following types:

1) problems that reveal the interdisciplinary content of the study material;

2) problems that contribute to the formation of interdisciplinary skills and abilities;

3) problems that fix the main methodological knowledge;

4) complex problems that require the use of cross-cutting knowledge, abilities, skills and methods [7, p. 9].

By the learning method, on the basis of which the interdisciplinary connection is realized, the interdisciplinary problems are divided into reproductive, search, problem. In the process of studying mathematical disciplines we apply all types of these problems, trying to increase the proportion of problem.

By the time characteristics we can distinguish retrospective, concomitant and perspective interdisciplinary problems [2]. In accordance with the organization of the educational process in colleges, students study mathematics during the first year as a general education discipline. Fundamental discipline "Higher Mathematics» is mastered by students during the second year. Therefore, among these types of problems, we use perspective and concomitant problems.

Solving of professionally directed mathematical problems is conducted in several steps. The researcher N. Samaruk defines the following stages of solving the problem. The first step is formalization. It means developing of the mathematical model of the problem: determining what is given in the problem, the analysis of the condition, description by the mathematical symbols of the interconnection between the data of the problem. The 
second step is to solve the problem within the built model. Selection of the required mathematical problem solving method is performed. The third step of interpretation - involves identifying of causal relationships in the economic phenomenon, analysis of the solution of the problem and its economic interpretation [2].

The conducted research of scientific literature allowed us to specify the main characteristics of problems with professional and economic component, that provide their high pedagogical significance:

a) independent transfer of students' mathematical knowledge, skills and abilities to the situation of a real economic activity;

b) a vision of new possibilities of using mathematical facts for the analysis and forecasting the economic processes and phenomena;

c) students' search of alternative ways of solving economic problems based on the application of mathematical methods and technologies [3].

Problems with professional content in the educational process perform a number of important functions:

- educational (the use of these problems is aimed at students' forming of the system of knowledge, skills and abilities at different stages of teaching mathematics);

- developmental (accomplishment of such problems develops the ability to comprehend the meaning of concepts, apply the acquired knowledge in practice, analyze the results obtained, make appropriate generalizations, comparisons, conclusions);

- up-bringing (the future specialist up-bringing at the mathematics classes can be carried out due to the specified problems);

- control (these problems are educational) [12].

We carried out problems solving at mathematical disciplines practical classes in several stages. At the propedeutic stage were used the reproductive problems that require reproduction of knowledge and its 
application in the familiar situation. Theses are the mathematical problems on the use of a certain formula, solving of which is carried out on a sample. The productive stage involves transformation from a simpler level of problems to a more complex one. This relates to mathematical problems. And also we introduce simple problems with professional content.

The purpose of modern education is to achieve the third stage creative. Here reproductive problems serve as a preparation for the formation of creative activity. At this stage, students learn to solve the problems of creative nature, both purely mathematical, and with interdisciplinary content [2]. As the research shows, this stage should be given considerable attention, since the purpose of studying mathematical disciplines is formation of an integrated system of knowledge, skills and abilities, which becomes the basis for the study of professional disciplines [2].

We will demonstrate the above-mentioned step-by-step problems solving while studying the topic «Derivative» of higher mathematics course. At the first stage, students solve simple problems on finding the derivative, thus forming the skill of using the table of derivatives and the rules of differentiation. At this stage, the development of purely mathematical skills of using the indicated mathematical apparatus is taken place. The second stage envisaged solving of non-standard mathematical problems for developing deeper skills of using the material. At the same stage, we introduce the solution of simple economic problems on samples, such as.

Example. The volume of production $U$, produced by the team of workers can be described by the equation $U=\frac{7}{6} t^{3}-\frac{5}{2} t^{2}+3 t+17$ where $t$ working hours. Find productivity of work in an hour after starting the work.

Solution. It is known that the standard working day is $0 \leq t \leq 8$. From lectures students know that productivity of work is a derivative of the volume of production. Consequently, the problem is reduced to finding the 
derivative and its value at a point $t=1$, that is $U^{\prime}(t)=\frac{7}{2} t^{3}-5 t^{2}+3$, $U^{\prime}(1)=\frac{7}{2} \cdot 1^{3}-5 \cdot 1^{2}+3=1,5$ (unit / hour).

At the third stage we offer students the problem that requires knowledge of some economic categories.

Example. The dependence between production costs and the volume of production produced by $x$ is determined by function $y=50 x-0,05 x^{3}$ (monetary unit). Determine average and marginal costs, provided that the output is 10 units.

Solution. The function of average costs (per unit of output) is expressed by the ratio $y_{\text {cep }}=\frac{y}{x}$. That is $y_{\text {cep }}=\frac{y}{x}=50-0,05 x^{2}$. At $x=10$ average costs (per unit of output) will be $y_{\text {cep }}(10)=50-0,05 \cdot 10^{2}=45$ (monetary units).

The marginal cost function is expressed by the derivative. At $x=10$ marginal cost will be $y_{\text {гран }}(10)=50-0,15 \cdot 10^{2}=35$ (monetary units).

Students are invited to conclude that if the average costs per unit production is 45 monetary units, then the marginal costs, that is, additional costs for the production of an additional unit of production at the given level of production (volume of production issued 10 units), make 35 monetary units. Solving of this problem requires students' knowledge of both economic categories (average and marginal costs), and the ability to find their values using the studied mathematical material.

Application in the educational process of problems with professional content has a number of advantages. Such problems:

1. contribute to the education of students' mathematical culture and literacy, since they provide an opportunity to illustrate the process of applying mathematics knowledge in solving problems in the work of an economist; 
2. form a positive psychological mood, increase self-esteem (students can see the real use of mathematics, and this induces them to actively study the disciplines);

3. contribute to the formation of necessary for the future economist personality qualities such as thinking, systemic character, multivariation, flexibility, criticality, non-contradiction, independence [2];

4. it is a powerful tool of interest and motivation, since most interdisciplinary problems are problem-oriented ones, which, in turn, stimulates students to master new knowledge [13, p. 288].

5. contribute to the formation of students' integrated knowledge, ability to develop mathematical models of economic processes, ability to select optimal mathematical methods for solving professional problems and, based on this, make practical recommendations [12].

6. form the idea of the place and possibilities of mathematics in the process of solving professional problems, which, in turn, contributes to overcoming skepticism about the usefulness of mathematics as one of the means of solving urgent nowadays problems [2].

As part of the recording experiment, we conducted analysis of the questionnaire of teachers-mathematicians and attending of classes in mathematical disciplines. These measures have shown that, despite the positive influence of application of economic problems during the study of mathematical disciplines, the mathematical training of specialists in the financial sphere is carried out in accordance with the traditional methodology. Practical classes on mathematical disciplines almost do not use problems with interdisciplinary content, lectures do not contain material reflecting the specialty. The lack of interdisciplinary material is due to ignorance by teachers of the problem of implementing links between disciplines, the limited volume of classroom hours in mathematics, the lack of teaching and methodological aid, and scientific literature on this issue. 
Therefore, in accordance with the need of improving the mathematical training of specialists in economic specialties, there appeared a question regarding selection and compilation of problems with professional and economical content, which should be carried out in accordance with requirements. Such problems have to:

- meet the sectoral standard for the future specialist training;

- describe the real professionally directed content, which reflects the practical significance and value of mathematical knowledge;

- to contribute to the formation of a positive motivation of students to their future professional activity;

- contain well-known (or understandable) terminology and conceptual apparatus [15, p. 80-81];

- correspond to the content of the professional activity tasks of future economists;

- contain basic and accessible problems characteristic of the economic sphere;

- correspond to logic and step-by-step solving of problems: from simple mathematical to problems with professional content;

- take into account also the time spent on the solution, therefore, it is sometimes advisable to make a detailed problem solving plan, due to the lack and limited time of the class hours, and offer the process of solving to students for self-study.

According to $\mathrm{O}$. Artiushenko, the main ways of compiling and selecting problems with professional content are the following:

1) reformulation of educational problems into problems with professionally directed content;

2) compilation of problems based on the data of scientific, popular science literature, the Internet;

3) the use of specific speciality disciplines material [16]. 
Therefore, on the basis of analysis of curricula, professional and practical training of future specialists in economic specialties, taking into account the aforementioned requirements and techniques, we have developed, according to the main sections of mathematics, a collection of professionally oriented problems, in which the most significant processes, phenomena and concepts of the economic branch are represented. The selection and compilation of problems were determined by the objectives of the training, which were focused on the formation of professional mathematical competence. The collection of problems provides economic and mathematical information, examples of solving problems with professional content, the problems were selected for classroom and independent solving. The themes for such problems are given in Table 1.

Table 1.

The themes of professionally directed problems in higher mathematics

\begin{tabular}{|l|l|}
\hline $\begin{array}{l}\text { Discipline chapter } \\
\text { «Higher mathemetics» }\end{array}$ & $\begin{array}{l}\text { The themes of problems with professional } \\
\text { content }\end{array}$ \\
\hline Linear Algebra & $\begin{array}{l}\text { Model of inter-sectoral balance of needs and } \\
\text { proposals. Problems on forecasts and evaluation } \\
\text { of functioning of enterprises, planning of } \\
\text { microeconomics of the enterprise }\end{array}$ \\
\hline Analytical geometry & $\begin{array}{l}\text { Formation of the equation of dependence } \\
\text { between different economic indicators and its } \\
\text { graphic representation. }\end{array}$ \\
\hline Calculus & $\begin{array}{l}\text { Sophisticated interests. Continuous accrual of } \\
\text { interests with their continuous capitalization }\end{array}$ \\
\hline $\begin{array}{l}\text { Differential Calculus of } \\
\text { one Variable functions }\end{array}$ & $\begin{array}{l}\text { to consume and marginal propensity to save. } \\
\text { Marginal cost. Labour productivity. }\end{array}$ \\
\hline
\end{tabular}




\begin{tabular}{|l|l|}
\hline $\begin{array}{l}\text { Integral calculus of one } \\
\text { variable functions }\end{array}$ & $\begin{array}{l}\text { Finding capital (fixed assets) by the known } \\
\text { investments. Cobb-Douglas function. Lorentz } \\
\text { curve. Discounting. }\end{array}$ \\
\hline $\begin{array}{l}\text { Differential Calculus of } \\
\text { Several Variables } \\
\text { functions }\end{array}$ & Compilation of production functions \\
\hline Differential equations & $\begin{array}{l}\text { Model of natural growth in a competitive market. } \\
\text { Logistic curve }\end{array}$ \\
\hline
\end{tabular}

Conclusion. From the above we can conclude that the introduction of problems with professional content in the practice of teaching mathematical disciplines is one of the conditions of increasing the level of mathematical training, actualization of students' cognitive activity, comprehensive development of personality, formation of integrated economic and mathematical knowledge, and, consequently, improvement of future professional activity.

\section{תimepamypa:}

1. Черненко Я. Профресійно спрямовані задачі в курсі математики ПТНЗ / Я. Черненко // Педагогічні науки: теорія, історія, інноваційні технології. - 2016. - № 9(63). - С. 201-210.

2. Самарук Н. М. Профресійна спрямованість навчання математичних дисциплін майбутніх економістів на основі міжпредметних зв'язків: дис. ... канд. пед. наук: 13.00.04 / Самарук Наталія Миколаївна. Тернопіль, 2008. - 229 с.

3. Серая Г. В. Формирование профрессионально-математической компетентности будущих экономистов в процессе решения учебных задач: автореф. дисс. на соискание науч. степени канд. пед. наук: 13.00.08 / Г. В. Серая. - Брянск, 2011. - 26 с. 
4. Гончаренко С. У. Український педагогічний словник/ C. У. Гончаренко. - К.: Либідь, 1997. - 476 с.

5. Беспалько В. П. Слагаемые педагогической технологии/ $B$. П. Беспалько. - М.: Педагогика, 1989. - 302 с.

6. Мирзоахмедов М. Методика обучения прикладных задач при углубленном изучении математики: автореф. дисс. на соискание учен. степени канд. пед. наук: спец. 13.00.02 «Теория и методика обучения и воспитания» / М. Мирзоахмедов. - М., 1990. - 16 с.

7. Шаповалова Л. А. Методика розв'язування задач міжпредметного змісту в прочесі навчання фрізики в загальноосвітній школі: авторефр. дис. на здобуття наук. ступеня канд. пед. наук: спец. 13.00 .02 «Теорія і методика навчання» / Л. А. Шаповалова. - К., 2002. - 20 с.

8. Бахмет В.И. Повышение эфрфективности профрессиональной подготовки студентов технического вуза в условиях задачного похода / В. И. Бахмет // Вестник развития науки и образования. 2008. - № 1. - C. 100-103.

9. Кашканова Г.Г. Использование игровых форм обучения общетехническим дисциплинам в процессе фрормирования профрессиональной направленности студентов: авторефр. дисс. ... на соискание науч. степ. канд. пед. наук: спец. 13.00 .01 «Общая педагогіка и история педагогики» / Г. Г. Кашканова. - К., 1992. - 19 с. 10. Шофреровська Л. С. Фінансові задачі в шкільному курсі математики / Л. С. Шофреровська // Теорія та методика навчання математики, фрізики, інформатики. - Кривий ріс: Видавничий відділ HМетAУ, 2002. - T.1: Теорія та методика навчання математики. C. $413-420$.

11. Иляшенко Л. К. Формирование математической компетентности будущего инженера по нефртегазовому делу: дисс. 
... канд. пед. наук: 13.00.08 / Любовь Киряловна Иляшенко.. - Сургут, 2010. -210 c.

12. Крилова Т. В. Шляхи активізації навчання математики у вищій технічній школі / Т. В. Крилова, П.О.Стеблянко, О. Ю. Орлова // Вісник Черкаського університету. Серія «Педагогічні науки». - 2010. № 181 . - C. 50-57.

13. Нічуговська Л. І. Науково-методичні основи математичної освіти студентів економічних спеціальностей вищих навчальних закладів: автореф. дис. на здобуття наук. ступеня д-ра пед. наук: спец. 13.00.04 «Теорія і методика профресійної освіти» / Л. І. Нічуговська. K., 2005. -36 c.

14. Фомкіна О. Г. Методична система проведення практичних занять з математики зі студентами економічних спеціальностей (на базі кооперативного інституту): авторефр. дис. на здобуття наук. ступеня канд. пед. наук: спец. 13.00.02 «Теорія і методика навчання» / О. Г. Фомкіна. - К., 2000. - 20 с.

15. Чумак О. О. Використання профресійно орієнтованих завдань у процесі навчання теорії ймовірностей та випадкових процесів майбутніх інженерів / О. О. Чумак // Вісник Черкаського університету. - 2015. - № 17 (350). - C. 79-84.

16. Артюшенко О. М. Використання задач профресійного спрямування / О. М. Артюшенко // Фізика в школах України. - № 9-10 (277-278) травень 2015 р. - C. 37-38.

\section{References:}

1. Chernenko Ja. Profesijno sprjamovani zadachi v kursi matematyky PTNZ / Ja. Chernenko // Pedaghoghichni nauky: teorija, istorija, innovacijni tekhnologhiji. - 2016. - № 9(63). - S. 201-210.

2. Samaruk N. M. Profesijna sprjamovanistj navchannja matematychnykh dyscyplin majbutnikh ekonomistiv na osnovi mizhpredmetnykh zv'jazkiv: 
dys. ... kand. ped. nauk: 13.00.04 / Samaruk Natalija Mykolajivna. Ternopilj, 2008. - $229 \mathrm{~s}$.

3. Seraya G. V. Formirovanie professionalno-matematicheskoy kompetentnosti budushchikh ekonomistov $v$ protsesse resheniya uchebnykh zadach: avtoref. diss. na soiskanie nauch. stepeni kand. ped. nauk: 13.00.08/ G. V. Seraya. - Bryansk, 2011. - 26 s.

4. Ghoncharenko S. U. Ukrajinsjkyj pedaghoghichnyj slovnyk / S.U. Ghoncharenko. - K.: Lybidj, 1997. - 476 s.

5. Bespalko V. P. Slagaemye pedagogicheskoy tekhnologii / V. P. Bespalko. - M.: Pedagogika, 1989. - 302 s.

6. Mirzoakhmedov M. Metodika obucheniya prikladnykh zadach pri uglublennom izuchenii matematiki: avtoref. diss. na soiskanie uchen. stepeni kand. ped. nauk: spets. 13.00.02 «Teoriya i metodika obucheniya $i$ vospitaniya» / M. Mirzoakhmedov. - M., 1990. - 16 s.

7. Shapovalova L. A. Metodika rozv'yazuvannya zadach mizhpredmetnogo zmistu v protsesi navchannya fiziki v zagalnoosvitniy shkoli: avtoref. dis. na zdobuttya nauk. stupenya kand. ped. nauk: spets. 13.00 .02 «Teoriya $i$ metodika navchannya» / L. A. Shapovalova. - K., 2002. - 20 s.

8. Bakhmet V. I. Povyshenie effektivnosti professionalnoy podgotovki studentov tekhnicheskogo vuza $v$ usloviyakh zadachnogo pokhoda / V. I. Bakhmet // Vestnik razvitiya nauki i obrazovaniya. - 2008. - № 1. S. $100-103$.

9. Kashkanova G. G. Ispolzovanie igrovykh form obucheniya obshchetekhnicheskim distsiplinam $v$ protsesse formirovaniya professionalnoy napravlennosti studentov: avtoref. diss. ... na soiskanie nauch. step. kand. ped. nauk: spets. 13.00.01 «Obshchaya pedagogika $i$ istoriya pedagogiki» / G. G. Kashkanova. - K., 1992. - 19 s.

10. Shoferovsjka L. S. Finansovi zadachi v shkiljnomu kursi matematyky / L.S. Shoferovsjka // Teorija ta metodyka navchannja matematyky, fizyky, 
informatyky. - Kryvyj righ: Vydavnychyj viddil NMetAU, 2002. - T.1: Teorija ta metodyka navchannja matematyky. - S. 413-420.

11. Ilyashenko L. K. Formirovanie matematicheskoy kompetentnosti budushchego inzhenera po neftegazovomu delu: diss. ... kand. ped. nauk: 13.00.08 / Lyubov Kiryalovna llyashenko.. - Surgut, 2010. - 210 s.

12. Krylova T. V. Shljakhy aktyvizaciji navchannja matematyky u vyshhij tekhnichnij shkoli / T. V. Krylova, P. O. Stebljanko, O. Ju. Orlova // Visnyk Cherkasjkogho universytetu. Serija «Pedaghoghichni nauky». - 2010. - № 181. - S. 50-57.

13. Nichughovsjka L.I. Naukovo-metodychni osnovy matematychnoji osvity studentiv ekonomichnykh specialjnostej vyshhykh navchaljnykh zakladiv : avtoref. dys. na zdobuttja nauk. stupenja d-ra ped. nauk: spec. 13.00.04 «Teorija i metodyka profesijnoji osvity» / L.I. Nichughovsjka. - K., 2005. $36 s$.

14. Fomkina O. Gh. Metodychna systema provedennja praktychnykh zanjatj z matematyky zi studentamy ekonomichnykh specialjnostej (na bazi kooperatyvnogho instytutu): avtoref. dys. na zdobuttja nauk. stupenja kand. ped. nauk: spec. 13.00.02 "Teorija $i$ metodyka navchannja» / O. Gh. Fomkina. - K., 2000. - 20 s.

15. Chumak O. O. Vykorystannja profesijno orijentovanykh zavdanj u procesi navchannja teoriji jmovirnostej ta vypadkovykh procesiv majbutnikh inzheneriv / O.O. Chumak // Visnyk Cherkasjkogho universytetu. - 2015. № 17 (350). - S. 79-84.

16. Artjushenko O. M. Vykorystannja zadach profesijnogho sprjamuvannja/ O. M. Artjushenko // Fizyka v shkolakh Ukrajiny. - № 9-10 (277-278) travenj 2015 r. - S. 37-38. 